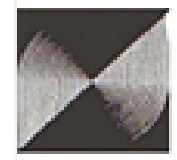

\section{Assicuttusa, \\ Sociedady Desarsollo}

Agricultura, Sociedad y Desarrollo

ISSN: $1870-5472$

asyd@colpos.mx

Colegio de Postgraduados

México

Martínez-Gutiérrez, Gabino Alberto; Díaz-Pichardo, René; Juárez-Luis, Griselda; Ortiz-Hernández,

Yolanda D.; López-Cruz, Juana Y.

CARACTERIZACIÓN DE LAS UNIDADES DE PRODUCCIÓN DE TOMATE EN INVERNADEROS DE

OAXACA

Agricultura, Sociedad y Desarrollo, vol. 11, núm. 2, abril-junio, 2014, pp. 153-165

Colegio de Postgraduados

Texcoco, Estado de México, México

Disponible en: http://www.redalyc.org/articulo.oa?id=360533099002

Cómo citar el artículo

- Número completo

- Más información del artículo

- Página de la revista en redalyc.org

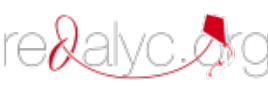

Sistema de Información Científica

Red de Revistas Científicas de América Latina, el Caribe, España y Portugal

Proyecto académico sin fines de lucro, desarrollado bajo la iniciativa de acceso abierto 


\title{
CARACTERIZACIÓN DE LAS UNIDADES DE PRODUCCIÓN DE TOMATE EN INVERNADEROS DE OAXACA
}

\author{
CHARACTERIZATION OF GREENHOUSE TOMATO PRODUCTION UNITS IN OAXACA
}

\author{
Gabino Alberto Martínez-Gutiérrez*, René Díaz-Pichardo, Griselda Juárez-Luis \\ Yolanda D. Ortiz-Hernández, Juana Y. López-Cruz
}

Instituto Politécnico Nacional. CIIDIR Unidad Oaxaca, Hornos 1003, C.P. 71230, Santa Cruz Xoxocotlán. Oaxaca. México. (gamartinezg@ipn.mx)

\begin{abstract}
RESUMEN
En los Valles Centrales de Oaxaca se localizan 118 unidades de producción, $30 \%$ de la superficie de tomate en invernaderos del estado. Estas unidades de producción son heterogéneas en sus niveles de desempeńo, rentabilidad y productividad. La teoría de la empresa basada en los recursos y en la ventaja comparativa propone que algunos recursos son estratégicos en las unidades de producción y permiten obtener ventajas comparativas y competitivas. Las unidades de producción carecen de organización; $30 \%$ han sido abandonadas y $32 \%$ de los invernaderos miden $2000 \mathrm{~m}^{2}$ y tienen 2.8 ańos en operación en promedio. El trabajo en estas unidades es familiar y sus integrantes tienen de 31 a 50 ańos de edad. Se concluye que para alcanzar la competitividad y aumentar el desempeño de las unidades de producción de tomate se deberá diseñar e implementar estrategias comerciales, financieras, organizativas, operacionales y ambientales.
\end{abstract}

Palabras clave: agricultura protegida, comercialización, empresas, estrategias comerciales, hortalizas.

\section{INTRODUCCIÓN}

A 1 igual que la agricultura protegida y la fertirrigación, la adopción de tecnologías es necesaria debido a la escasez del agua, al deterioro e infertilidad del suelo y a la variación micro-climática (SAGARPA, 2009). La agricultura protegida se define como un sistema agrícola especializado en el cual se lleva a cabo un cierto control del medio edafoclimático, alterando sus condiciones: suelo, temperatura, radiación solar, viento, humedad y composición atmosférica (Castellanos-Ramos, 2004). Mediante estos sistemas de protección

\footnotetext{
* Autor responsable $*$ Author for correspondence.

Recibido: septiembre, 2013. Aprobado: diciembre, 2013.

Publicado como ARTÍCULO en ASyD 11: 153-165. 2014.
}

\begin{abstract}
In Oaxaca's Central Valleys, there are 118 production units, $30 \%$ of the greenhouse surface for tomatoes in the state. These production units are varied in their levels of performance, profitability and productivity. The theory of enterprise based on resources and on the comparative advantage suggests that some resources are strategic in the production units, and they allow obtaining comparative and competitive advantages. The production units lack organization; $30 \%$ have been abandoned and $32 \%$ of the greenhouses measure $2000 \mathrm{~m}^{2}$ and have been operating for 2.8 years, in average. The labor in these units is familiar and members are between 31 and 50 years of age. The conclusion is that in order to reach competitiveness and increase the performance of tomato production units, commercial, financial, organizational, operational and environmental strategies should be designed and implemented.
\end{abstract}

Key words: protected agriculture, commercialization, enterprises, commercial strategies, vegetables.

\section{INTRODUCTION}

$s$ in protected agriculture and fertirrigation,
the adoption of technologies is necessary
due to water scarcity, soil deterioration and infertility, and micro-climate variation (SAGARPA, 2009). Protected agriculture is defined as a specialized agricultural system where a specific control of the soil-climate environment is carried out, altering its conditions: soil, temperature, solar radiation, wind, moisture and atmospheric composition (Castellanos-Ramos, 2004). Plants are cultivated within these protection systems, modifying their natural environment to extend the harvesting period, alter the conventional cycles, increase the yields and improve their quality, stabilize production and have 
se cultivan plantas, modificando su entorno natural para prolongar el periodo de recolección, alterar los ciclos convencionales, aumentar los rendimientos y mejorar su calidad, estabilizar las producciones y disponer de producto cuando la producción al aire libre se encuentra limitada (Castilla, 2005). En México, la agricultura protegida va en ascenso día a día para maximizar los rendimientos y la calidad de las cosechas de productos hortícolas durante todo el año, además de utilizar eficientemente los recursos disponibles (OEIDRUS, 2011). De esta manera, la agricultura protegida paulatinamente ha cobrado relevancia, sobre todo para el cultivo de tomate, obedeciendo a las necesidades de garantizar la calidad e inocuidad del producto y obtener volúmenes de producción y rendimientos superiores en comparación a los obtenidos en campo abierto (Alcantar-González et al., 1999; Villarreal-Romero et al., 2002).

En el estado de Oaxaca existe un crecimiento ascendente en el cultivo de tomate en invernaderos, pasando de cero hectáreas en 1990 a 147 en 2008 (OEIDRUS, 2011). Actualmente, el Comité Estatal Sistema Producto Tomate de Oaxaca tiene registradas 420 hectáreas de tomate cultivado en invernaderos, con una derrama de 240 millones anuales. Esta cadena productiva involucra 4200 productores, de los cuales $18.1 \%$ son mujeres (Méndez-Sánchez, 2013). De esta superficie, $45 \%$ se localiza en la región de la Mixteca, $30.6 \%$ en los Valles Centrales, $14.3 \%$ en la Sierra Sur, $12.2 \%$ en las Sierra Norte y $9.6 \%$ restante en las regiones, Istmo, Costa, Papalopan y Cañada (OEIDRUS, 2011). Sin embargo, y a pesar de tratarse de una misma región geográfica, las unidades de producción son heterogéneas en sus niveles de desempeño, rentabilidad y productividad, considerando indicadores de nivel tecnológico, como: eficiencia, experiencia productiva, dependencia económica y tamaño. El Comité Estatal Sistema Producto de Tomate de Oaxaca ha identificado cinco niveles de desempeńo: muy bajo, bajo, medio, alto y muy alto, donde cerca de $72 \%$ de las unidades de producción tienen un desempeño por debajo del nivel medio (comunicación personal ${ }^{1}$ ). Esta información refleja que los niveles pobres de desempeño constituyen una barrera que limita el crecimiento y la consolidación del sector.

En la región de los Valles Centrales de Oaxaca se encuentran los módulos o unidades de producción bajo invernadero más compactos del estado, donde the product available when open air production is limited (Castilla, 2005). In México, protected agriculture is rising day by day, in order to maximize yields and the quality of harvests of vegetable products during the whole year, in addition to efficiently using the resources available (OEIDRUS, 2011). Thus, protected agriculture has gradually taken on importance, particularly for the tomato crop, responding to the needs for guaranteeing the quality and harmlessness of the product and of obtaining higher production volumes and yields in comparison to those obtained in the open field (Alcantar-González et al., 1999; Villarreal-Romero et al., 2002).

In the state of Oaxaca, there is an ascending growth in the cultivation of greenhouses tomatoes, which went from zero hectares in 1990 to 147 in 2008 (OEIDRUS, 2011). Currently, the State System Committee for Tomato Product in Oaxaca has 420 hectares of tomato grown in greenhouses registered, with a spill of 240 million annually. This productive chain involves 4200 producers, of which $18.1 \%$ are women (Méndez-Sánchez, 2013). Of this surface, $45 \%$ is located in the Mixteca region, $30.6 \%$ in the Central Valleys, $14.3 \%$ in the Sierra Sur, $12.2 \%$ in the Sierra Norte and the other $9.6 \%$ in the regions of Isthmus, Coast, Papaloapan and Cañada (OEIDRUS, 2011). However, and in spite of being the same geographic region, the production units are heterogeneous in their levels of performance, profitability and productivity, taking into account indicators of the technological level, such as: efficiency, productive experience, economic dependency and size. The State System Committee for Tomato Product in Oaxaca has identified five levels of performance: very low, low, medium, high and very high; close to $72 \%$ of the production units have a performance below the medium level (personal communication ${ }^{1}$ ). This information reflects that the poor levels of performance constitute a barrier that limits growth and consolidation in the sector.

The smallest greenhouse modules or production units of the state are found in the region of Oaxaca's Central Valleys, where the main problem for smallscale producers is organization (Guzmán-Corral, 2013). In this sense, agricultural production units understood as an organization that occupies a limited place in time and space, where certain relationships of design, organization, decision-making and 
el principal problema de los pequeños productores es la organización (Guzmán-Corral, 2013). En este sentido, las unidades de producción agrícola entendidas como una organización que ocupa un lugar delimitado en el tiempo y en el espacio, en el que prevalecen determinadas relaciones de diseño, organización, toma y ejecución de decisiones, tecnología, producción, especialización y comercialización, para obtener un resultado económico y social favorable (Fong-Reynoso, 2005) Además, desarrollan nuevos esquemas de emprendimientos económicos, en los que la agricultura protegida toma relevancia.

Por otra parte, un recurso es todo aquello que pueda ser considerado como una fortaleza o debilidad de una empresa. Éstos pueden ser definidos como aquellos activos (tangibles e intangibles) que están vinculados semipermanentemente con la empresa. Los primeros corresponden a bienes físicos y los segundos a los no físicos, siendo los últimos los más valiosos para lograr un desempeño superior. Los recursos intangibles se basan comúnmente en los conjuntos de conocimiento de la empresa y son la principal fuente de desempeño (Edelman et al., 2005; Hughes y Morgan, 2007).

Por lo tanto, es necesario conocer los recursos, entendidos éstos como los bienes tangibles e intangibles a disposición de la unidad de producción para producir eficiente $y / o$ eficazmente una oferta que tiene valor para algún(os) segmento(s) de mercado (Hunt y Morgan, 1995) con que cuentan las unidades de producción de tomate en invernaderos y definir adecuadamente estrategias que contribuyan al logro de un mayor desempeño e impulsar el desarrollo económico de este importante sector.

Debido a lo anterior, el presente trabajo tuvo como objetivo estudiar las relaciones entre los recursos, las estrategias comerciales y el desempeño de las unidades de producción de tomate en invernaderos de los Valles Centrales de Oaxaca y determinar las características de las unidades productivas en relación con las dimensiones de la superficie cultivada, número de plantas, meses de cosecha y costos de producción, así como las características de los productores en cuanto a edad, nivel de escolaridad y experiencia.

\section{Materiales y Métodos}

La población objetivo del estudio correspondió a las unidades de producción de tomate en invernadero implementation, technology, production, specialization and commercialization prevail, so as to obtain favorable economic and social results (Fong-Reynoso, 2005). In addition, they develop new schemes for economic enterprises, where protected agriculture becomes important.

On the other hand, a resource is anything that can be considered a strength or weakness of an enterprise. They can be defined as those assets (tangible and intangible) that are linked semi-permanently with the enterprise. The first correspond to physical goods and the second to non-physical, with the latter being the most valuable to achieve a higher performance. The intangible resources are commonly based in the sets of knowledge of the enterprise and are the main source of performance (Edelman et al., 2005; Hughes and Morgan, 2007).

Therefore, it is necessary to explore the resources, understood as the tangible and intangible goods at the disposal of the production unit to produce efficiently and/or effectively an offer that has value for some segment(s) of the market (Hung and Morgan, 1995), with which greenhouse tomato production units can count, and to adequately define strategies that contribute to achieving a greater performance and driving the economic development of this important sector.

Due to this, the study had the objective of analyzing the relationships between the resources, the commercial strategies and the performance of the greenhouse tomato production units in Oaxaca's Central Valleys, to determine the characteristics of productive units with regard to the dimensions of the surface cultivated, the number of plants, the months of harvest, and the production costs, as well as the characteristics of producers in terms of age, schooling and experience.

\section{Materials ANd Methods}

The target population for the study was the greenhouse tomato production units in Oaxaca's Central Valleys, located between geographic coordinates $16^{\circ} 23^{\prime}$ and $17^{\circ} 32^{\prime}$ North latitude, and between 96 $02^{\prime}$ and 97० 00' West longitude, at an average altitude of $1100 \mathrm{~m}$ above sea level (INEGI, 2010).

The total population considered is registered in the document "Greenhouses, basic data 2008" 
de los Valles Centrales de Oaxaca, localizadas entre las coordenadas geográficas $16^{\circ} 23^{\prime}$ y $17^{\circ} 32^{\prime}$ de latitud norte, y entre los $96^{\circ} 02^{\prime}$ y $97^{\circ} 00^{\prime}$ de longitud oeste, a una altura promedio de $1100 \mathrm{~m}$ sobre el nivel del mar (INEGI, 2010).

Se consideró la población total que se encuentra registrada en el documento "Invernaderos, datos básicos 2008” de la Oficina Estatal de Información para el Desarrollo Rural Sustentable de Oaxaca (OEIDRUS, 2011) y se siguió una metodología deductiva que consistió en tres fases. En la primera se realizó una revisión de artículos científicos, libros, periódicos, bases de datos, páginas web y demás fuentes de información secundaria con la cual se elaboraron; el marco teórico contextual y el trabajo de investigación en campo. En la segunda se hicieron entrevistas a dueños de siete unidades de producción de tomate en invernadero. El contenido de esta información fue analizada con el programa WEFT QDA. A partir de estos resultados y de la revisión de la literatura realizada en la primera fase se diseñó una prueba piloto que consistió en un cuestionario con preguntas cerradas de valoración que se calificaron a través de una escala Likert de cinco puntos y dicotómicas (MoralesVallejo et al., 2011a), el cual fue aplicado a dueńos, encargados o representantes legales de ocho unidades de producción. Una vez validado y corregido el cuestionario empleado en la prueba piloto, en la tercera fase se aplicó el cuestionario definitivo a 118 unidades de producción, conteniendo preguntas cerradas de valoración que se calificaron nuevamente a través de la escala Likert de cinco puntos. El cuestionario final contó con un total de 111 reactivos.

Para la selección de las unidades de producción de tomate en invernaderos, incluidas en la muestra, se tomaron en cuenta los siguientes criterios de selección:

1. Ubicación geográfica. Unidades de producción ubicadas dentro de los límites geográficos de la Región Valles Centrales de Oaxaca.

2. Producto cultivado: unidades de producción productoras de tomate.

3. Tipo de estructura de protección empleada: Unidades de producción que cultivan sólo en invernadero (no aplica otro tipo de estructura de protección como macro túnel, micro túnel, bioespacios, etcétera).

4. Status de operación. Unidades productivas activas al momento de la encuesta. from the State Information Office for Sustainable Rural Development in Oaxaca (Oficina Estatal de Información para el Desarrollo Rural Sustentable de Oaxaca, OEIDRUS, 2011), and a deductive methodology was followed that consisted in three phases. In the first, a review of scientific articles, books, newspapers, databases, web pages and other secondary sources of information was performed, with which thecontextual theoretical framework and field research were elaborated. In the second, interviews were made with the owners of seven greenhouse tomato production units. The content of this information was analyzed with the WEFT QDA software. From these results and the literature review performed during the first phase, a pilot test was designed consisting of closed questions for valuation, graded through a Likert scale of five points, and dichotomous (Morales-Vallejo et al., 2011a); it was applied to owners, managers or legal representatives of eight production units. Once the questionnaire used for the pilot test was validated and corrected, during the third phase the definitive questionnaire was applied to 118 production units, containing closed questions for valuation that were newly graded through a fivepoint Likert scale. The final questionnaire had a total of 111 questions.

For the selection of greenhouse tomato production units included in the sample, the following selection criteria were used:

1. Geographic location. Production units located within the geographic limits of the region of Oaxaca's Central Valleys.

2. Product cultivated. Tomato-producing production units.

3. Type of protection structure used. Production units that cultivate only in greenhouses (does not apply to other types of protection structure such as macro tunnel, micro tunnel, biospace, etc.)

4. Status of operation. Production units active at the time of the survey.

With these characteristics, 298 production units were identified in Oaxaca's Central Valleys.

From the identification of the population, the size of the sample was determined through the statistical equation for a finite population (Equation 1) and a level of trust of $95 \%$. 
Bajo estas características se identificaron 298 unidades de producción en los Valles Centrales de Oaxaca.

A partir de la identificación de la población, el tamaño de la muestra se determinó a través de la ecuación estadística para población finita (Ecuación 1) y un nivel de confianza de $95 \%$.

Para determinar el tamaño de la muestra (población) se utilizó la ecuación propuesta por MoralesVallejo (2011b):

$$
n=\frac{N}{\frac{(N-1) e^{2}}{z^{2} p q}+1}
$$

donde:

$n=$ tamaño de la muestra

$z=$ valor normal estándar al nivel de confianza de 95

$\%=1.96$

$p=$ probabilidad de éxito $=0.5$

$q=$ probabilidad de fracaso $=0.5$

$N=$ tamaño conocido de la población $=298$

$e=$ error muestral $=0.07$

Por lo anterior, el tamaño de la muestra fue de 118 unidades de producción, distribuidas en los siete distritos que conforman la región Valles Centrales de Oaxaca.

Para garantizar la representatividad de cada Distrito se realizó la selección de la muestra, considerando el porcentaje que el número de unidades de producción de cada Distrito representa con respecto al total. Mediante una regla de tres simple se determinó el tamaño de la sub-muestra para cada uno de los distritos. De esta manera se identificó la unidad de análisis como la unidad de producción de tomate en invernaderos de los Valles Centrales de Oaxaca que, de acuerdo con Fong-Reynoso (2005), se define como la unidad económica que ocupa un lugar delimitado en el tiempo y el espacio, prevaleciendo determinadas relaciones de diseño, organización, toma y ejecución de decisiones, y que se dedica a la producción y comercialización de tomate en invernadero y está ubicada dentro de los límites geográficos de la región en estudio.

Se aplicaron 118 cuestionarios completos a dueños, encargados o representantes legales de las unidades de producción, logrando cubrir $100 \%$ del tamaño de muestra determinada (Cuadro 1).
To determine the size of the sample (population), the equation proposed by Morales-Vallejo (2011b) was used:

$$
n=\frac{N}{\frac{(N-1) e^{2}}{z^{2} p q}+1}
$$

where:

$n=$ size of the sample

$z=$ standard normal value at the level of trust of 95

$\%=1.96$

$p=$ probability of success $=0.5$

$q=$ probability of failure $=0.5$

$N=$ known size of the population $=298$

$e=$ simple error $=0.07$

Because of this, the size of the simple was 118 production units, distributed in the seven districts that make up the region of Oaxaca's Central Valleys.

In order to guarantee the representation of each District, the sample selection was performed taking into account the percentage that the number of production units in each District represents with regard to the total. Through simple crossmultiplication, the size of the sub-sample was determined for each one of the districts. Thus, the unit of analysis was identified as the greenhouse

Cuadro 1. Total de unidades de producción visitadas y encuestadas.

Table 1. Total number of production units visited and surveyed.

\begin{tabular}{lccc}
\hline Distrito & Población & U.P. visitadas & $\begin{array}{c}\text { Encuestas } \\
\text { realizadas }\end{array}$ \\
\hline Centro & 38 & 21 & 15 \\
Ejutla & 56 & 26 & 22 \\
Etla & 48 & 24 & 19 \\
Ocotlán & 54 & 25 & 21 \\
Tlacolula & 50 & 26 & 20 \\
Zaachila & 15 & 7 & 6 \\
Zimatlán & 37 & 18 & 15 \\
\hline Total & 298 & 147 & 118 \\
\hline
\end{tabular}

Fuente: encuestas aplicadas en el período mayo-julio 2011. U.P.: Unidades de Producción. • Source: interviews applied during the May-July 2011 period. U.P.: Production Units. 
En términos generales se observó buena disposición por parte de los encuestados para participar en el proceso. En todos los distritos se visitó un número mayor de unidades de producción al indicado para cada sub-muestra, esto debido a que en algunos casos no se logró localizar al dueño, encargado o representante legal, por diversas razones, tales como la ausencia de horarios formales de trabajo o que la unidad de producción se encontraba fuera de periodo de cultivo y estaban abandonadas o sólo algún trabajador se encontraba realizando labores de limpieza.

Los datos obtenidos en las encuestas aplicadas a las unidades de producción de tomate en invernadero se analizaron con el programa estadístico para ciencias sociales (SPSS v. 21) para validar las escalas y determinar su confiabilidad (Castañeda et. al., 2010).

\section{Resultados y Discusión}

Las unidades de producción de tomate localizadas en los Valles Centrales de Oaxaca son las más productivas del estado (Méndez-Sánchez, 2013). En esta región existen 378 unidades de producción, de las cuales 303 estaban activas y 75 inactivas. De las primeras, 288 se dedican a la producción de tomate (OEIDRUS, 2011). Respecto a los recursos físicos dominantes reportados en estas unidades de producción y obtenidos mediante las encuestas efectuadas (Cuadro 3 ¿2?), resultó que $32 \%$ de estas unidades son relativamente nuevas. Iniciaron con esta actividad en tomato production unit in Oaxaca's Central Valleys, which, based on Fong-Reynoso (2005), is defined as the economic unit that occupies a limited place in time and space, with certain relationships prevailing of design, organization, decision-making and execution, and which is devoted to the production and commercialization of greenhouse tomato and is located within the geographic limits of the region in study.

Questionnaires (118) were applied to owners, managers or legal representatives of the production units, and $100 \%$ of the sample size determined was covered (Table 1).

In general terms, a good disposition for participating in the process was observed from those interviewed. In all the districts a higher number of production units than those indicated was visited for each sub-sample, because in some cases the owner, manager or legal representative was not found, for various reasons, such as the absence of formal work hours or the production unit being outside the cultivation period and abandoned, or only some worker was found performing cleaning tasks.

The data obtained from the surveys applied to the greenhouse tomato production units were analyzed with the statistical program for social sciences (SPSS v. 21), to validate the scales and determine their reliability (Castañeda et. al., 2010).

Cuadro 2. Condiciones dominantes de los invernaderos en las unidades de producción con invernadero en Valles Centrales de Oaxaca.

Table 2. Dominating conditions of greenhouses in production units with greenhouses in Oaxaca's Central Valleys.

\begin{tabular}{lllc}
\hline Factores & \multicolumn{1}{c}{ Indicadores } & Condición dominante & Porcentaje respecto al total \\
\hline \multirow{2}{*}{ Infraestructura } & Inicio de operaciones & 2006 & 32 \\
& Condición & Muy bueno & 45 \\
& Material & Metálica & 98 \\
Asistencia técnica & Cortinas & Laterales y cenitales & 44 \\
& Cubierta & Plástico & 91 \\
Riego & Tipo & En fertilización & 91 \\
& Fuente & Asesor pagado & 50 \\
Insumos utilizados & Clase de riego & Tecnificado & 93 \\
Equipo de medición & Sistema de riego & Por goteo (cintilla) & 69 \\
\hline
\end{tabular}

Fuente: encuestas aplicadas en el periodo mayo-julio, 2011. Source: interviews applied during the May-July 2011 period. 
Cuadro 3. Organización de las unidades de producción con invernaderos en Valles Centrales de Oaxaca Table 3. Organization of production units with greenhouses in Oaxaca's Central Valleys.

\begin{tabular}{lllc}
\hline Factores & \multicolumn{1}{c}{ Indicadores } & Condición dominante & Porcentaje respecto al total \\
\hline Organización & Forma & Individual & 48.8 \\
Inversión & Fuente Inicial de Recursos & Apoyo Federal/Estatal & 77.6 \\
Mano de obra & Fuente & Familia & 62.6 \\
Oferta del producto & Mercado Principal & Local & 74.7 \\
\hline
\end{tabular}

Fuente: encuestas aplicadas en el periodo mayo-julio, 2011. Source: interviews applied during the May-July 2011 period.

2006 y la condición dominante fue en infraestructura (invernaderos metálicos, con cubierta de plástico) y una condición buena para operar, además de la tecnología mínima necesaria (riego por goteo y equipos de medición).

En estas unidades de producción estudiadas se encontró también que $82 \%$ de las personas que laboran son hombres y $18 \%$ mujeres, que coincide con lo señalado por Méndez-Sánchez (2013), con una edad promedio de 41 ańos y experiencia en la actividad de 2.8 años.

En cuanto a organización para el trabajo entre las diferentes unidades, la forma más representativa fue la individual (48.8\%), mientras que al interior de cada unidad fue por grupos familiares donde las actividades operativas son distribuidas entre sus miembros y la obtención de los recursos iniciales de inversión es por medio de Dependencias FederalesEstatales, siendo el mercado local el lugar donde ofertan con mayor frecuencia sus productos (Cuadro 3).

Por otra parte, la edad de $56 \%$ de los productores de tomate en los Valles Centrales de Oaxaca fluctúa de los 31-50 años, con escolaridad mínima de primaria y con poca experiencia en el manejo del tomate en invernaderos (1 a 3 ańos); además, las ventas del producto que obtiene $60 \%$ de los productores no alcanza para satisfacer sus necesidades económicas familiares; por lo tanto, abandonan esta actividad y, en el mejor de los casos, recurren a la siembra de básicos $y$ en otros a las remesas de los familiares que trabajan en los Estados Unidos (Cuadro 4).

Por lo anterior $19 \%$ del total de las unidades de producción con invernadero han sido abandonadas, lo cual es $13 \%$ mayor a lo que menciona el Comité Estatal Sistema Producto Tomate de Oaxaca (comunicación personal); quienes también señalan que el $30 \%$ de los invernaderos se encuentran en esta situación, quedando como inversiones totalmente infructíferas, debido al

\section{Results AND Discussion}

The tomato production units located in Oaxaca's Central Valleys are the most productive of the state (Méndez-Sánchez, 2013). In this region there are 378 production units, of which 303 were active and 75 inactive. Of the first, 288 are devoted to tomato production (OEIDRUS, 2011). Regarding the dominating physical resources reported in these production units and obtained through the surveys performed (Table $3 / 2$ ?), it turned out that $32 \%$ of these units are relatively new. They began with this activity in 2006 and the dominating condition was in infrastructure (metallic greenhouses, with plastic covers) and a good condition to operate, in addition to the minimum necessary technology (drip irrigation and measuring equipment).

In these production units studied, it was also found that $82 \%$ of the people who work are men and $18 \%$ women, which agrees with reports by Méndez-Sánchez (2013), with an average age of 41 years and 2.8 years of experience in the activity.

In terms of organization for labor among the different units, the most representative manner was individual $(48.8 \%)$, while inside each unit it was by family groups, where the operative activities are distributed between its members; obtaining the initial investment resources is through federal-state offices, and the local market is the place where their products are sold most frequently (Table 3 ).

On the other hand, the age of $56 \%$ of the tomato producers in Oaxaca's Central Valleys ranges from 31 to 50 years, with minimum schooling of primary and little experience in greenhouse tomato management ( 1 to 3 years); in addition, the sales from the product that $60 \%$ of the producers obtain is not enough to satisfy their family economic needs; therefore, they abandon this activity and, in the best case, turn to 
Cuadro 4. Principales atributos de los productores en las unidades de producción con invernadero en Valles Centrales de Oaxaca. Table 4. Main attributes of producers in greenhouse production units in Oaxaca's Central Valleys.

\begin{tabular}{lcccc}
\hline Atributos & Promedio & Máximo & Mínimo & Porcentaje más alto (\%) \\
\hline Edad (años) & 44 & 81 & 20 & 56 (31 a 50 años) \\
Escolaridad & Primaria & Secundaria & Sin estudio & Primaria \\
Hombres (totales) & $82 \%$ & - & - & - \\
Mujeres (totales) & $18 \%$ & - & 0.8 & 54 (1 a 3 años) \\
Experiencia en el manejo (años) & 2.8 & 14 & 10 & 60 \\
\hline Ingresos por venta de tomate (\%) & 32 & 60 & & - \\
\hline
\end{tabular}

Fuente: encuestas aplicadas en el periodo mayo-julio, 2011. Source: interviews applied during the May-July 2011 period.

alto costo que la infraestructura representa, la cual una vez abandonada es muy costosa su rehabilitación.

De las encuestas realizadas se encontró que los productores que abandonan dicha actividad son aquéllos que presentan por lo menos uno de los siguientes problemas:

a. Ausencia de sistemas sólidos de comercialización que permitan al productor tener certeza en la venta de sus productos a precios justos, lo que provoca desaliento y abandono. Ante la ausencia de estos esquemas comerciales se ven obligados a malbaratar su producción e, inclusive, no recuperan su inversión.

b. Deficiencias en la administración de las unidades de producción, asociadas a la falta de financiamientos adecuados. Los productores carecen de sistemas organizativos que les permitan gestionar y ser eficientes en sus recursos, por lo que frecuentemente los ingresos generados de las ventas no son correctamente invertidos y, por lo general, los financiamientos del mercado son con intereses muy elevados y de difícil acceso.

c. Asociacionismo deficiente. Aunque debería ser un elemento a favor del desarrollo, el hecho de compartir los costos, beneficios e incluso riesgos de manera colaborativa, puede provocar que llegue a convertirse en el elemento detonador del abandono de la actividad como consecuencia de desacuerdos, falta de organización y la prevalencia de intereses personales que impiden la convivencia y el trabajo armónico.

d. El cultivo de tomate no es la actividad principal del productor o tiene actividades alternas o complementarias que le representan beneficios mayores. cultivating basics and in others to remittances from family members who work in the United States (Table 4).

Therefore, $19 \%$ of the total of greenhouse production units have been abandoned, which is $13 \%$ higher than reported by the State System Committee for Tomato Product in Oaxaca (personal communication); they also suggest that $30 \%$ of the greenhouses are in this situation, left as totally unsuccessful investments, due to the high cost that infrastructure represents, which once abandoned is very costly to repair.

From the surveys performed, it was found that the producers who abandon such activity are those who have at least one of the following problems:

a. Absence of solid commercialization systems that allow producers to have certainty in the sale of their products at fair prices, causing discouragement and abandonment. In face of the absence of these commercial schemes, they are forced to sell their products at a loss and could even fail to recover their investment.

b. Deficiencies in administration of the production units, associated to the lack of adequate financing. The producers lack organizational systems that allow them to manage and be efficient with their resources, which is why the income generated from sales is frequently not invested correctly, and generally, market financing has very high interest rates and is difficult to access.

c. Deficient associationism. Although it should be an element in favor of development, sharing costs, benefits and even risks in a cooperative manner could lead to it becoming the detonating element for abandonment of the activity as consequence 
Cuadro 5. Indicadores productivos de la actividad agrícola en condiciones de invernadero. Table 5. Production indicators of agricultural activity under greenhouse conditions.

\begin{tabular}{|c|c|c|c|c|}
\hline Atributos & Promedio & Máximo & Mínimo & Moda \\
\hline Superficie $\mathrm{m}^{2}$ & 2000.0 & 15000.0 & 250.0 & 1000.0 \\
\hline Planta $\mathrm{m}^{-2}$ & 3.5 & 10.0 & 2.0 & 3.0 \\
\hline Número de racimos & 12.5 & 30.0 & 4.0 & 12.0 \\
\hline Meses de cosecha & 8.0 & 12.0 & 4.0 & 7.0 \\
\hline
\end{tabular}

Fuente: encuestas aplicadas en el periodo mayo-julio 2011. Source: interviews applied during the May-July 2011 period.

e. Escasa experiencia. Algunos productores deciden tomar el reto de la producción sin tener los conocimientos mínimos para desarrollar la actividad. En algunos casos solo se les presenta la oportunidad de obtener apoyos para la compra de invernaderos y optan por aprovechar el beneficio sin tener metas claras de desarrollo.

En relación con algunos indicadores de la producción de tomate de invernadero se destaca que la superficie cultivada es de $2000 \mathrm{~m}^{2}$ en promedio por unidad productiva, con una superficie máxima de $15000 \mathrm{~m}^{2}$ y una mínima de $250 \mathrm{~m}^{2}$. En el caso de la plantación por $\mathrm{m}^{2}$ se destaca una máxima de 10 plantas por $\mathrm{m}^{2}$, una mínima de 2 plantas por $\mathrm{m}^{2}$ y un promedio de 3.5 plantas por $\mathrm{m}^{2}$ (Cuadro 5).

Es importante hacer notar que, a diferencia de otros contextos (sobre todo en empresas convencionales), los recursos tangibles son relevantes para el desempeño de la unidad de producción. Esto es así porque el sector aún se encuentra en una etapa de crecimiento y consolidación y, dadas las limitantes en cuanto al acceso a recursos físicos que aquejan al sector, contar con recursos de este tipo hace la diferencia a la hora de obtener resultados.

Dado que se probó el efecto mediador de las estrategias comerciales, los resultados de este estudio también refuerzan el planteamiento teórico de Barney (1991 y 2001) en su teoría basada en recursos, quien argumenta que los recursos de la empresa permiten concebir e implementar estrategias que pueden ser fuente de ventaja competitiva sostenible y favorecer su desempeño.

En la medida en que el productor agrícola y los trabajadores obtengan información y conocimientos del mercado, seleccionen adecuadamente el segmento de mercado al cual servir, tengan la capacidad de identificar y contactar clientes, cumplan los requisitos of disagreements, lack of organization, and prevalence of personal interests that hinder the coexistence and harmonious work.

d. Tomato cultivation is not the primary activity of the producer or he/she has alternative or complementary activities that represent greater benefits.

e. Scarce experience. Some producers decide to take on the challenge of production without having the minimum knowledge to develop the activity. In some cases, they are only presented with the opportunity to obtain support for the purchase of greenhouses and they decide to take advantage of the benefit without having clear development goals.

With regard to some indicators of greenhouse tomato production, it should be noted that the surface cultivated is $2000 \mathrm{~m}^{2}$ in average per productive unit, with a maximum surface of 15000 $\mathrm{m}^{2}$ and a minimum one of $250 \mathrm{~m}^{2}$. In the case of the plantation per $\mathrm{m}^{2}$, a maximum of 10 plants per $\mathrm{m}^{2}$ is reported, a minimum of 2 plants per $\mathrm{m}^{2}$, and an average of 3.5 plants per $\mathrm{m}^{2}$ (Table 2).

It is important to highlight that, as opposed to other contexts (particularly conventional enterprises), the tangible resources are relevant for the performance of the production unit. This is so because the sector is still in a growth and consolidation stage and, given the limitations in terms of access to physical resources that trouble the sector, having resources of this type can be the difference at the time of obtaining resources.

Since the mediating effect of commercial strategies was tested, the results from this study also reinforce the theoretic approach by Barney (1991 and 2001) in his theory based on resources, who argues that the resources of an enterprise allow conceiving and 
comerciales que el mercado demanda y desarrollen relaciones de trabajo sanas y benéficas con el gobierno y con otros productores, podrán establecer una adecuada estrategia comercial que, sin duda alguna, repercutirá en su desempeño.

Es importante mencionar que durante los reactivos correspondientes a la dimensión resultados de mercado surge la necesidad de desarrollar nuevos estudios para la propuesta de reactivos y la medición de los resultados en el sector específico, puesto que una gran parte de la literatura existente sobre el tema está enfocada a las empresas convencionales y la ausencia de investigaciones de este tipo se hace notar en el sector agrícola.

Por lo tanto, para aumentar la productividad del tomate es necesario disminuir los costos de producción, a fin de ser más competitivos vía precio ya que, actualmente, debido a los precios más elevados, buena parte del producto que se consume en Oaxaca proviene de otros Estados de la República Mexicana, lo que afecta seriamente al productor local (CIDRS, 2009). Dicha disminución se podría lograr con la potencialización de los recursos disponibles y con la eficiencia de estrategias comerciales, las cuales redundarán en un mayor desempeño en las unidades de producción.

La buena clasificación y presentación del producto favorece la comercialización y propicia la obtención de mejores precios para el productor, aspectos que actualmente son una debilidad de los productores de los Valles Centrales (Guzmán-Corral, 2013; Méndez-Sánchez, 2013). Esto también está muy relacionado con anteriores investigaciones en las cuales sólo se había probado el efecto mediador de las estrategias de negocio (Edelman et al., 2005; Beleska et al., 2012). En este estudio se demuestra el papel mediador de las estrategias comerciales en la relación recursos-desempeño.

Por otra parte, Guzmán-Corral (2013) menciona que para exportar el tomate se requiere: 1) la organización formal económica de los productores; 2) la capacitación constante y dinámica de la calidad y la productividad (cantidad por metro cuadrado que permita que esto sea rentable con la sanidad e inocuidad que exigen los mercados); y 3) la capacitación con visión empresarial. En este sentido, los productores de los valles centrales y de la Sierra Sur, que son los que se encuentran más organizados, enfocan todos sus esfuerzos para lograrlo. Sin embargo, los implementing strategies that can be the source of a sustainable competitive advantage and may favor their performance.

Insofar as the agricultural producer and workers obtain information and knowledge from the market, adequately select the market segment to serve, have the ability to identify and contact clients, fulfill the commercial requirements that the market demands, and develop healthy and beneficial working relationships with the government and other producers, they will be able to establish an adequate commercial strategy that, without a doubt, will have an effect on their performance.

It is important to mention that during the questions that correspond to the dimension of market results, there arises the need to develop new studies in order to suggest questions and measurement of results in the specific sector, since a large part of the existing literature about the theme is focused on conventional enterprises and the lack of research of this type in the agricultural sector stands out.

Therefore, in order to increase tomato productivity it is necessary to decrease the production costs so as to be more competitive through prices, since currently, due to the higher prices, a large amount of the product consumed in Oaxaca is from other states in the Mexican Republic, which gravely affects the local producers (CIDRS, 2009). This decrease could be achieved with the potentialization of available resources and with the efficiency of commercial strategies, which would result in a better performance of production units.

The good classification and presentation of the product favors commercialization and fosters obtaining better prices for the producer, aspects that are currently a weakness of producers in the Central Valleys (Guzmán-Corral, 2013; Méndez-Sánchez, 2013). This is also closely related to prior research which had tested only the mediating effect of the business strategies (Edelman et al., 2005; Beleska et al., 2012). In this study, the mediating role of commercial strategies in the resource-performance relationship is shown.

On the other hand, Guzmán-Corral (2013) mentions that in order to export tomato, the following is required: 1) formal economic organization of producers; 2) constant and dynamic training of quality and productivity (amount per square meter that allows for this to be profitable with the health and 
apoyos gubernamentales en temas de capacitación y seguimiento en la fase de comercialización, muy a menudo son nulos o carentes de efectividad; si a esto se suma el hecho de que algunos productores son expertos en la fase de producción, pero pobres en capacidades comerciales, la comercializacion se convierte en uno de los mayores retos para el productor agrícola (Romero-Arenas et al., 2008; Pramanik y Prakash, 2010; Méndez-Sánchez, 2013).

Los resultados señalan que, dada la problemática del mercado, en las unidades de producción el desempeño es resultado en gran medida de las estrategias comerciales que desarrollan las unidades de producción a partir de sus recursos disponibles. De esta manera, cuanto mayores sean los recursos y éstos sean explotados y canalizados para el desarrollo de estrategias comerciales eficientes, la unidad de producción podrá lograr un mejor desempeño. Así, por ejemplo, en la medida en que la unidad de producción pueda poner en práctica nuevas ideas, seleccionar adecuadamente el mercado, poseer conocimientos acerca de la labor de venta, identificar clientes potenciales, tener la habilidad de hacer contactos en nuevos mercados y contar con información de mercado, la unidad de producción podrá diferenciar su producto de la competencia (a partir del diseño de empaques y etiqueta). Por ejemplo, podrá elegir correctamente sus canales de comercialización y desarrollar la manera idónea de promocionar su producto. Todo esto, en conjunto, le permitirá lograr sus fines comerciales y obtener un mejor desempeño.

Consolidar relaciones con el gobierno también favorece el desarrollo de las estrategias comerciales en las unidades de producción, puesto que los subsidios y apoyos económicos del gobierno son canalizados para el desarrollo de actividades tendientes a lograr una diferenciación del producto, como selección, empaque y etiquetado. Las relaciones también permiten el acercamiento a ciertos canales de comercialización $\mathrm{e}$, incluso en algunas ocasiones, es el gobierno quien de manera directa ha apoyado a algunas unidades de producción a realizar negociaciones de compra-venta con empresas privadas. Mantener las relaciones con el gobierno también implica lograr una mejor reputación para la unidad de producción, pues ello brinda al productor una carta de presentación que servirá como medio de promoción para sus productos.

Todo ello permitirá que el mercado tenga una mayor confianza en la unidad de producción, lo que se harmlessness that markets demand); and 3) training with entrepreneurial vision. In this sense, producers from the central valleys and Sierra Sur, who are the ones best organized, focus all their efforts on achieving it. However, government support in training and followup issues during the commercialization phase are very often null or lack effectiveness; if, in addition to this, we take into account the fact that some producers are experts in the production phase, although lacking commercial abilities, marketing becomes one of the biggest challenges for the agricultural producer (Romero-Arenas et al., 2008; Pramanik and Prakash, 2010; Méndez-Sánchez, 2013).

The results suggest that, given the market problematic, the performance in production units is the result, largely, of commercial strategies developed by the production unit from its resources available. Thus, the higher the resources are and the better they are exploited and channeled for the development of efficient commercial strategies, the production unit will achieve a better performance. Therefore, for example, to the degree that the production unit can implement new ideas, adequately select the market, have knowledge about the sales labor, identify potential clients, have the ability to make contacts in new markets and have market information, the production unit will be able to differentiate its product from the competition (starting with the design of packaging and labels). For example, it will be able to correctly choose its marketing channels and develop the ideal way of promoting its product. All this, in conjunction, will allow it to achieve its commercial goals and obtain a better performance.

Consolidating relationships with the government also favors the development of commercial strategies in production units, since the subsidies and financial supports from the government are channeled for the development of activities that tend to achieve the differentiation of the product, such as selection, packaging and labeling. The relationships also allow approaching certain commercialization channels and, on some occasions, the government has even directly supported some production units to carry out purchase-sale negotiations with private companies. Maintaining relationships with the government also implies attaining a better reputation for the production unit, for this provides the producer with a presentation letter that will serve as a means of promotion for its products. 
traducirá en mayores ingresos y, por lo tanto, un desempeño financiero superior. Además, mayores ventas facilitarán que el productor cuente con los recursos financieros necesarios para invertir en actividades propias del ámbito ambiental, tendientes, por ejemplo, a la conservación y aprovechamiento sustentable de los recursos agua y suelo. De la misma manera, las relaciones con otros productores agrícolas permitirán fortalecer las estrategias comerciales, consolidando un mayor volumen de producción, servir a otros segmentos de mercado y lograr beneficios económicos más seguros.

\section{Conclusiones}

De las unidades de producción de tomate en invernaderos de los Valles Centrales de Oaxaca, $32 \%$ son relativamente nuevas (2.8 años), carecen de organización entre unidades de producción y tienen en promedio $2000 \mathrm{~m}^{2}$ de invernaderos. El trabajo organizativo al interior de cada unidad de producción es mayoritariamente familiar, realizado por personas de mediana edad (31-50 ańos), de las cuales $18 \%$ son mujeres. El ingreso por venta de tomate no alcanza a satisfacer sus necesidades familiares, siendo esta una de las razones por la cual $30 \%$ de la superficie de invernaderos está abandonada.

Para alcanzar la competitividad y aumentar el desempeño de las unidades de producción de tomate en invernaderos de los Valles Centrales de Oaxaca, los responsables de cada unidad deberán conocer y valorar no solamente las técnicas tradicionales de producción sino, además, los recursos tangibles e intangibles de carácter interno y externo con que cuenta cada unidad producción para que, de esta forma, se diseñen e implementen estrategias comerciales, financieras, organizativas operacionales y ambientales.

\section{Notas}

${ }^{1}$ ElComitéEstatal SistemaProducto TomatedeOaxaca (CESPTO) es un órgano integrado por los actores que participan en la Cadena Productiva de Tomate en el Estado de Oaxaca y se encuentra respaldada con la figura legal denominada "Comité Estatal Sistema Producto Tomate y Hortalizas de Oaxaca A.C.", apoyada por la Secretaría de Agricultura, Ganadería, Desarrollo Rural, Pesca y Alimentación (SAGARPA) y el Gobierno del Estado de Oaxaca. System Committee for Tomato Product in Oaxaca
All of this will allow for the market to have greater confidence in the production unit, which will translate into higher income and, therefore, a superior financial performance. Also, higher sales will make it easier for the producer to have the financial resources necessary to invest in activities typical of the environmental scope which lead, for example, to the conservation and sustainable use of the water and soil resources. Similarly, relationships with other agricultural producers will allow strengthening commercial strategies, consolidating a higher production volume, serving other market segments and achieving more secure economic benefits.

\section{Conclusions}

Of the greenhouse tomato production units in Oaxaca's Central Valleys, $32 \%$ are relatively new (2.8 years), they lack organization between production units, and have an average of $2000 \mathrm{~m}^{2}$ in greenhouses. The organizational work inside each production unit is mostly familiar, performed by middle-aged people (31-50 years), of which $18 \%$ are women. The income from tomato sales is not enough to satisfy their family needs, with this being one of the reasons why $30 \%$ of the greenhouse surface is abandoned.

In order to achieve competitiveness and increase the performance of the greenhouse tomato production units in Oaxaca's Central Valleys, those responsible for each unit should understand and value not only traditional production techniques, but also, in addition, the tangible and intangible resources of internal and external nature which each production unit has, so that commercial, financial, organizational, operative and environmental strategies can be designed and implemented.

- End of the English version -

(Comité Estatal Sistema Producto Tomate de Oaxaca, CESPTO) is an organization made up by the actors who participate in the tomato productive chain in the state of Oaxaca, and they are supported with the legal figure of "State System Committee for Tomato and Vegetable Product of Oaxaca, A.C.", supported by the Ministry of Agriculture, Livestock Production, Rural Development, Fishery and Food (Secretaria de Agricultura, Ganadería, Desarrollo Rural, Pesca y 
Alimentación, SAGARPA) and the government of the state of Oaxaca.

\section{Literatura Citada}

Alcantar-González, Ernesto Gabriel, Manuel Villarreal-Romero, y Andrés Aguilar- Santelises.1999. Tomato growth (Lycopersicon esculentum Mill.) and nutrient utilization in response to varying fertigation programs. Acta Horticulturae 481, 385391.

Barney, Jay. 1991. Firm resources and sustained competitive advantage. Journal of Management, 17 (1), 99-120.

Barney, Jay. 2001. Is the Resources-Based "View" a useful perspective for strategic management research? Yes. Academy of Management Review, 26 (1), 41-56.

Beleska, Spasova Elena, Keith W. Glaister, and Chris Stride. 2012. Resource determinants of strategy and performance: The case of British exporters. Journal of World Business, 47 (4), 635-647.

Castilla, Nicolás. 2005. Invernaderos de plástico. Tecnología y Manejo. Ed. Mundi-Prensa. Madrid, España. 459 p.

Castañeda, María Belén, Alberto F. Cabrera, Yadira Navarro, y Wietse de Vries. 2010. Procesamiento de datos y análisis estadísticos utilizando SPSS: Un libro práctico para investigadores y administradores educativos. Editora Universitária da PUCRS, EDIPUCRS: Porto Alegre, RS Brasil. 164 p.

Castellanos-Ramos, Javier Zaragoza. 2004. Manejo de la fertirrigación en suelo. In: Manual de Producción Hortícola en Invernadero. J Z Castellanos-Ramos (ed). 2a. ed. ITAGRI. México, pp: 103-123.

CIDRS (Comisión Intersecretarial para el Desarrollo Rural Sustentable). 2009. Sistema Nacional de Investigación y Transferencia Tecnológica para el Desarrollo Rural Sustentable. Recuperado el 10 de noviembre de 2011, de SNITT: www. snitt.org.mx

Edelman, Linda. F., Candida G. Brush, and Tatiana Manolova. 2005. Co-alignment in the resource-performance relationship: strategy as mediator. Journal of Business Venturing, 20 (3), 359-383.

Fong-Reynoso, Carlos. 2005. La teoría de los recursos y capacidades: Fundamentos microeconómicos 1a. Edición. Universidad de Guadalajara, Coordinación General Académica, Unidad para el Desarrollo de la Investigación y el Posgrado. Guadalajara, México. 132 p.

Guzmán-Corral, Edgar. 2013. Productores de Oaxaca exportan tomate. Recuperado el 28 de julio de 2013 de: http://www. horticultivos.com/component/content/article/41-noticiasrecientes/343-productores-de-oaxaca-exportan-tomate
Hunt, Shelby D., and Robert M. Morgan. 1995. The comparative advantage theory of competition. Journal of Marketing, 59, 1-15.

Hughes, Paul, and Robert E. Morgan. 2007. A resource-advantage perspective of product-market strategy performance and strategic capital in high technology firms. Industrial Marketing Management, 36 (4), 503-517.

INEGI (Instituto Nacional de Estadística Geografía e Informática). 2010. Marco geoestadistico municipal. Catálogo de entidades municipales y localidades. Recuperado el 20 de julio de 2013 en: http://www.inegi.org.mx/geo/contenidos/ geoestadistica/CatalogoClaves.aspx

Méndez-Sánchez, Sandro Guadalupe. 2013. Integra feria del tomate a 4,200 productores en Oaxaca. Recuperado el 28 de julio de 2013 en: http://horticultivos.com/component/ content/article/41-noticias-recientes/475-integra-feria-deltomate-a-4-mil-200-productores-en-oaxaca

Morales-Vallejo, Pedro. 2011a. Guía para construir cuestionarios y escales de actitudes. Versión electrónica disponible. Recuperada el 12 de enero del 2013 en http://www.upcomillas. es/personal/peter/otrosdocumentos/guiaparaconstruirescalasdeactitudes.pdf

Morales-Vallejo, Pedro. 2011b. Estadística aplicada a las Ciencias Sociales .Tamańo necesario de la muestra: ¿Cuántos sujetos necesitamos? Facultad de Humanidades. Universidad Pontificia Comillas. Madrid. España, pp: 1-24.

OEIDRUS (Oficina Estatal de Información para el Desarrollo Rural Sustentable). 2011. Invernaderos Datos Básicos 2008. Recuperado el 22 de noviembre de 2011, de OEIDRUS: http://www.oeidrus-oaxaca.gob.mx/invernaderos2008.htm

Pramanik, Rupali, and Gyan Prakash. 2010. Marketable surplus and marketing efficiency of vegetables in Indore District: a micro-level study. The IUP Journal of Agricultural Economics, 7 (3), 84-93.

Romero-Arenas, Omar, Manuel Huerta-Lara, y Delfino ReyesLópez. 2008. Metodología para conformar una empresa comercializadora de productos agropecuarios como estrategia para el desarrollo de zonas agrícolas. Revista Mexicana de Agronegocios, XII. 23, 658-666.

SAGARPA (Secretaría de Agricultura, Ganadería, Desarrollo Rural, Pesca y Alimentación). 2009. Programa de ejecución directa 2009, Agricultura Protegida. México. Recuperado el 26 de Agosto de 2012, en: http://www.sagarpa.gob.mx/ programas $2 /$ evaluacionesExternas/Lists/Otras\%20Evaluaciones/Attachments/14/Informe\%20Funcionamiento\%20 y\%20Operacion\%20Soporte.pdf

Villarreal-Romero Manuel, Raymundo S. García-Estrada,Tomas Osuna-Enciso, y Adolfo D. Armenta-Bojorquez. 2002. Efecto de dosis y fuente de nitrógeno en rendimiento y calidad de poscosecha de tomate en fertirriego. Terra, 20 (3), 311-320. 